\title{
An Analytical Study of the Current Status of White Meat and its Expenditure in Fayoum Governorate
}

\author{
Yehia M.M. Khalil, Fatima A. Shafiq, Soheir Mokhtar and Nagwa M. El-agroudy
}

Department of Agricultural Economic, Agricultural and Biological Research Division, National Research Centre, 33 El Buhouth St., 12622 Dokki, Giza, Egypt.

Received: 10 July 2020 / Accepted 30 August 2020 / Publication date: 15 Sept. 2020

\begin{abstract}
The research aims to study the current status of protein production from poultry in Egypt. This is in addition to examining its most important economic indicators during the period (2000-2018) and studying the Expenditure Function of the study sample at different income levels. Moreover, the study relied on the secondary data collected from the Central Agency for Public Mobilization and Statistics and the Ministry of Agriculture. Besides, it depends mainly on the primary data collected through the questionnaire form for a random sample consisting of 312 families from Fayoum Governorate distributed as follows 147 families from the urban areas of the Fayoum Center, 165 families from the countryside of the Fayoum Center in 2019. The study conspicuously showed the statistically significant increase in the production, consumption, and average per capita share of poultry by about $45,53.7$ thousand tons per year, $8.5 \mathrm{~kg} /$ year respectively. Additionally, it becomes obviously clear from the study that the self-sufficiency ratio for each of the poultry showed a significant decrease of about $0.62 \%$. Through studying consumption expenditure on poultry in the three categories of the study sample, it showed that there was a statistically significant direct relationship between expenditure on poultry and each of the monthly income and the number of family members. Besides, there is an inverse relationship with the poultry price in rural and urban areas, and that poultry are a luxury commodity in the first and second category of low income. Additionally, it has been shown that one of the most important causes of the food gap of animal protein is the steady increase in population number, which amounted to about 100 million people in 2019 along with the high level of living (the third category to be addressed by the study for example). Thus, domestic consumption increases, resulting in an increase in the gap size.
\end{abstract}

Keywords: consumer expenditure, poultry, expenditure elasticity

\section{Introduction}

Food is conspicuously at the forefront in human needs, as food security conditions in Egypt are linked to two basic aspects. The first is the state of food production at the local level and the extent of its closeness to achieved levels of self-sufficiency. The second is the extent of food availability and the ability of community members to obtain healthy acceptable rates of calories from that food. Moreover, animal protein is one of the most important components of food because it contains amino acids that the body cannot form or replace what is lost from them. Besides, its importance is due to the fact that it helps body to grow and compensate what is damaged. Additionally, it helps in metabolic processes and its deficiency causes many diseases. Despite this importance of animal protein, the average annual per capita share in Egypt is lower than the preventive limit recommended by both organizations: the World Health Organization (WHO) and the Food and Agriculture Organization (FAO). This average ranges from (33-40) gram of protein per day. As the daily average of animal protein per capita in Egypt in 2019 reached about 22 gram of protein / day, so there is a protein gap that a person suffers from in Egypt.

\section{Problem of the Study}

The problem is represented in the inability of local production of white meat protein and not pursuing the increased demand, which has resulted in a food gap of protein amounting to about 31

Corresponding Author: Yehia M.M. Khalil, Department of Agricultural Economic, Agricultural and Biological Research Division, National Research Centre, 33 El Buhouth St., 12622 Dokki, Giza, Egypt. 
thousand tons. This has prompted the country to import from abroad at prices that go up from year to year, which affects negatively on prices, the average per capita share of the commodity and imbalance in the commercial performance, with increasing burden on the balance of payments and the country's trade balance

\section{Objective of the Study}

The research aims to study the current status of protein production from poultry in Egypt. This is in addition to examining its most important economic indicators during the period (2000-2018) and studying the Expenditure Function of the study sample at different income levels.

\section{Methodology of the Study and Data Sources}

The study used the Descriptive Analysis Approach in describing the problem in addition to the Quantitative Analysis using some different measurements such as the General Trend, as well as the Multiple Regression that was used in estimating the Elasticity Functions of the study sample.

Moreover, the study relied on the secondary data collected from the Central Agency for Public Mobilization and Statistics and the Ministry of Agriculture. Besides, it depends mainly on the primary data collected through the questionnaire form for a random sample consisting of 312 families from Fayoum Governorate distributed as follows 147 families from the urban areas of the Fayoum Center, 165 families from the countryside of the Fayoum Center in 2019.

\section{The Development of Some Productive and Consumer Indicators for Poultry in the Arab Republic of Egypt}

Through studying the amount of poultry production at the national level during the period (2000-2018), it becomes obviously clear that it ranged between a minimum and a maximum of about 578,1386 thousand tons in 2000, 2018, respectively, with an increase rate estimated at $140 \%$ of the minimum. Besides, through estimating the general time trend equation for the production amount during the study period, the statistically significant annual increase represented about $4.7 \%$ of the average of the production amount. Consequently, the Determination Coefficient was 0.91 , as is evident from equation (1) in Table (1) of the study. By studying the consumption of poultry meat at the national level, it ranged between a minimum and a maximum of about 577, 1488 thousand tons in 2000-2018, respectively, with an increase of about $158 \%$ over the minimum. Besides, through estimating the general time trend equation of the consumption of poultry meat during the same period, the statistically significant annual increase is obviously clear. It is estimated and represented by about $5.3 \%$ of the average consumption amount. The Determination Coefficient reached 0.92 as shown in equation (2) with the same table, while it became clear that the per capita of poultry meat at the national level ranged between a minimum and a maximum of about $8,15.6 \mathrm{~kg} /$ year during the year 2001 and 2018, respectively, with an increase representing about $95 \%$ of the minimum. Moreover, through estimating the general time trend equation of the individual of poultry meat during the study period, the annual statistically significant increase is estimated at $8.5 \mathrm{~kg} /$ year, representing about $3.2 \%$ of the average per capita, estimated at $12.6 \mathrm{~kg} /$ year. This Determination Coefficient reached 0.82 , as shown by equation (3) in the same table. Additionally, it becomes obviously clear that the percentage of self-sufficiency in poultry meat ranged between a minimum and a maximum of about $85 \%, 105 \%$ in 2008 and 2016 , with an increase of about $23.5 \%$ over the minimum. Through estimating the general time trend equation of the self-sufficiency of poultry meat during the study period, we found the statistically significant annual deficiency estimated at $0.62 \%$, representing about $0.89 \%$ of the average estimated at about $70 \%$. The Determination Coefficient was 0.65 , as shown by the equation in Table (3) in the same table. 
Table 1: General Time Trend Equations for the Quantity of Production, Consumption, and Selfsufficiency of Poultry during the Period (2000-2018)

\begin{tabular}{|c|c|c|c|c|}
\hline Statement Coefficient & Equation & $\begin{array}{c}\text { Determination } \\
\text { Coefficient }\end{array}$ & Average & $\begin{array}{c}\text { Change } \\
\text { Rate }\end{array}$ \\
\hline 1-Production (Thousand tons) & $\begin{array}{r}\mathrm{Y}^{\wedge} \mathrm{e}=513+45 \times \mathrm{e} \\
(13.5)^{* *}\end{array}$ & 0.91 & 963 & 4.7 \\
\hline $\begin{array}{l}\text { 2-Consumption (Thousand } \\
\text { tons) }\end{array}$ & $\begin{array}{r}\mathrm{Y}^{\wedge} \mathrm{e}=468+53.7 \mathrm{x} \mathrm{e} \\
(13.7)^{* *}\end{array}$ & 0.92 & 1005 & 5.3 \\
\hline $\begin{array}{l}\text { 3-What concerns the individual } \\
\mathrm{kg} \text { / year }\end{array}$ & $\begin{array}{r}\mathrm{Y}^{\wedge} \mathrm{e}=8.5+0.405 \mathrm{x} \mathrm{e} \\
(8.9)^{* *}\end{array}$ & 0.82 & 12.6 & 3.2 \\
\hline 4- Self-sufficiency\% & $\begin{array}{r}\mathrm{Y}^{\wedge} \mathrm{e}=103-0.62 \times \mathrm{e} \\
(-5.5)^{* *}\end{array}$ & -0.65 & 96.9 & 0.64 \\
\hline
\end{tabular}

Where $\mathrm{Y}^{\wedge}$ indicates the estimated value of the dependent variable

$\mathrm{x}$ e indicates the element of time as an independent variable, where $\mathrm{e}(1,2,3,4 \ldots \ldots .19)$.

** Significant at the level of $1 \%$

* Significant at the level of $5 \%$

Source: Collected and calculated from the study sample data in Fayoum Governorate in 2019

Individual Consumption and Expenditure on Poultry among the Study Sample

It becomes obviously clear from the study that the monthly consumption per capita from poultry among the urban of the study sample in the first category amounted to about $1.083 \mathrm{~kg} / \mathrm{month}$, while in the countryside it reached about $0.917 \mathrm{~kg} /$ month, with an increase of about $18.2 \%$, for the urban area compared to the rural. Moreover, what concerns the individual of poultry among the urban of the study sample in the second category amounted to about $1.667 \mathrm{~kg} /$ month, while its counterpart in the countryside reached about $01.333 \mathrm{~kg} /$ month with an increase for the urban area estimated at about $25 \%$ compared to its counterpart in the countryside. The monthly consumption per capita from poultry among the urban of the study sample in the third category amounted to about $2.167 \mathrm{~kg} /$ month, while it reached about $1.917 \mathrm{~kg} /$ month at the countryside with an increase for the urban population by about $11.53 \%$ for its counterpart in the countryside. As for the prices, it was evident that their closeness in the urban and the rural areas.

As for the monthly family expenditure of poultry among the urban of the study sample in the first category amounted to about 178.8 pounds / month, while it amounted to about 166.8 pounds in the countryside / month with an increase of urban over the countryside estimated at $6.7 \%$. Moreover, the monthly expenditure in the second category in urban areas was 291.7 pounds / month while it was 240 pounds / month in the countryside. The increase in urban areas over the countryside represents about $17.7 \%$. Additionally, the monthly urban expenditure for the third category is about 346.7 pounds / month, while in the countryside it reached about 335.4 pounds / month. This increase for urbanites represents about $3.2 \%$ for its counterpart in the countryside, as shown in Table (2).

Table 2: The Selected Sample in the Urban and Rural Areas of Fayoum, Per capita Consumption, Consumer Prices, Household Income, and Monthly Expenditure on Poultry in 2019

\begin{tabular}{|c|c|c|c|c|c|c|}
\hline \multirow{2}{*}{ Statement } & \multicolumn{2}{|c|}{ First Category } & \multicolumn{2}{|c|}{ Second Category } & \multicolumn{2}{|c|}{ Third Category } \\
\hline & Urban & Rural & Urban & Rural & Urban & Rural \\
\hline Number of Families & 30 & 35 & 80 & 85 & 37 & 45 \\
\hline Number of Family Members & 5 & 7 & 5 & 6 & 4 & 5 \\
\hline Family's Monthly Income & 1853 & 1537 & 3670 & 3150 & 6550 & 5218 \\
\hline What concerns the individual ( $\mathrm{kg} /$ month) & 1.083 & 0.917 & 1.667 & 1.333 & 2.167 & 1.917 \\
\hline Total Meat kg / year & 2.917 & 2.417 & 4.250 & 3.417 & 5.500 & 4.750 \\
\hline Red Meat Price (kg / pounds) & 100 & 80 & 115 & 110 & 125 & 110 \\
\hline Poultry Price (kg / pounds) & 33 & 26 & 35 & 30 & 40 & 35 \\
\hline Fish Price (kg / pounds) & 30 & 25 & 40 & 35 & 50 & 40 \\
\hline Poultry Expenditure / pound & 178.8 & 166.8 & 291.7 & 240.0 & 346.7 & 335.4 \\
\hline Total Expenditure / pound & 716.3 & 686.0 & 1214.6 & 1127.5 & 1463.3 & 1339.6 \\
\hline
\end{tabular}

Source: Collected and calculated from the study sample data in Fayoum Governorate in 2019 


\section{Third: Factors Affecting Consumption Expenditure on Poultry in Urban and Rural Areas}

The relationship between consumption expenditure on poultry (Y) was studied as a dependent factor, and the independent factors affecting it are the number of family members (x1), the price of red meat (x2), the price of poultry (x3), and the price of fish (x4), the monthly income of the head of the household (x5). Besides, income, commodity price, and alternative commodity prices were used for each type of meat, whether red meat or fish. The stage regression was used by the double logarithmic approach to determine the most important factors affecting consumption expenditure on different types of meat among the study sample in rural and urban areas of different income groups.

\section{1- Consumer Expenditure on Poultry Meat in Urban and Rural Areas of the Three Categories of the Study Sample}

Estimates of function No. $(1,2)$ shown in Table (3) refer to the statistically significant and positive relationship between monthly expenditure on poultry meat in Fayoum urban and rural areas. The first category is (less than 2000 pounds) of the study sample, which considers poultry as a luxury commodity for them due to the low monthly income of the family and between the number of family members (x1), monthly income by pounds (x5), where expenditure elasticity was estimated by about $0.92,0.51$ for urban and $0.86,0.71$ for the countryside. It consequently means that expenditure on poultry meat increases with an increase in the number of family members and monthly income, while the inverse relationship became clear between expenditure on poultry meat and its price per kilogram (x3) in the first category.

Table 3: Stage Regression Equations for the Most Important Affecting Factors on Expenditure for Poultry in the Urban and Rural Areas of Fayoum among the Three Study Categories in 2019.

\begin{tabular}{|c|c|c|c|c|c|}
\hline Categories & $\begin{array}{l}\text { Equation } \\
\text { No. }\end{array}$ & Statement & Equation & R. & F. \\
\hline \multirow{2}{*}{$\begin{array}{l}\text { First } \\
\text { Category }\end{array}$} & 1 & Urban & $\begin{array}{c}\mathrm{LN} \mathrm{Y}^{\wedge} \mathrm{e}=1.02+0.92 \mathrm{LN} \times 1 \mathrm{e}-037 \mathrm{LN} \times 3 \mathrm{e}+0.51 \mathrm{LN} \times 5 \mathrm{e} \\
(10) * * \quad(-2.6)^{* *}(2.3) * *\end{array}$ & 0.76 & 59 \\
\hline & 2 & Rural & $\begin{array}{c}\mathrm{LN} \mathrm{Y}_{\mathrm{e}}=0.31+0.86 \mathrm{LN} \mathrm{x}_{1 \mathrm{e}}-0.61 \mathrm{LN} \mathrm{x}_{3 \mathrm{e}}+0.710 \mathrm{LN} \mathrm{x}_{5 \mathrm{e}} \\
(13.5)^{* *} \quad(-3.8)^{* *} \quad(4.4)^{* *}\end{array}$ & 0.86 & 72 \\
\hline \multirow[b]{2}{*}{$\begin{array}{l}\text { Second } \\
\text { Category }\end{array}$} & 3 & Urban & $\begin{array}{c}\mathrm{LN} \mathrm{Y}^{\wedge} \mathrm{e}=1.74+1.11 \mathrm{LN} \times 1 \mathrm{e}-0.465 \mathrm{LN} \times 4 \mathrm{e} \\
(15)^{* *} \quad(-2.5)^{* *}\end{array}$ & 0.69 & 112 \\
\hline & 4 & Rural & $\begin{array}{l}\mathrm{LN} \mathrm{Y}^{\wedge} \mathrm{e}=0.31+1.02 \mathrm{LN} \times 1 \mathrm{e}+0.357 \mathrm{LN} \times 2 \mathrm{e}+0.2190 \mathrm{LN} \times \\
5 \mathrm{e} \\
(19)^{* *}\end{array}$ & 0.70 & 120 \\
\hline \multirow{2}{*}{$\begin{array}{l}\text { Third } \\
\text { Category }\end{array}$} & 5 & Urban & $\begin{array}{c}\mathrm{LN} \mathrm{Y}^{\wedge} \mathrm{e}=1.8+0.121 \mathrm{LN} \times 1 \mathrm{e}+0.51 \mathrm{LN} \times 5 \mathrm{e} \\
(12.5)^{* *} \quad(3.8)^{* *}\end{array}$ & 0.87 & 81 \\
\hline & 6 & Rural & 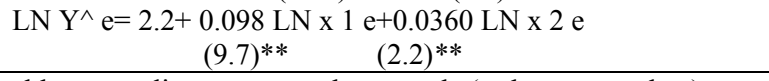 & 0.82 & 125 \\
\hline
\end{tabular}

Where: $\mathrm{Y}^{\wedge} \mathrm{e}$ the estimated value of the monthly expenditure on meat by pounds (red meat, poultry)

$\mathrm{x}_{\mathrm{le}}$ : The number of family members

$\mathrm{x}_{2 \mathrm{e}}$ : The price of a kilogram of red meat by pound

$\mathrm{x}_{2 \mathrm{e}}$ : The price per kilogram of poultry meat by pound

$\mathrm{x}_{5 \mathrm{e}}$ : Average of monthly household income by pound

$(* *)$ significant at the level of significance by $0.01,(*)$ significant at the level of significance by 0.05 , the value in parentheses indicates the calculated value $(\mathrm{T})$

Source: Collected and calculated from the study sample data in Fayoum Governorate in 2019.

Moreover, estimates of function (3) indicate the positive and statistically significant relationship between monthly expenditure on poultry meat in the urban of Fayoum, the second category (2000-4000 pounds), and the number of family members (x1). Moreover, the expenditure elasticity was estimated at 1.11 , which means that expenditure on poultry meat increases with an increase in the number of family members, while the inverse relationship between expenditure on poultry meat and the price per kilogram of it (x3) became clear, meaning that with a decrease in the price of poultry, expenditure on it increases. As for the countryside in the same category, estimates of function (4) indicate the positive and statistically significant relationship between the monthly expenditure on poultry meat and between each of the following; (the number of family members (x1), the price of red meat (x2), and the monthly income by pounds (x5). The expenditure elasticity was 
estimated at about $1.02,0.357$, and 0.219 , respectively, which means that expenditure on poultry meat increases with an increase in the number of family members, the price of a kilogram of red meat and the monthly income of the family. Besides, equation (5.6) indicates the statistically positive and significant relationship between the monthly expenditure on poultry meat in the urban and rural areas in Fayoum in the third category (4000 pounds or more) among the study sample and between each of the number of family members (x1), the monthly income by pounds (x5). The expenditure elasticity was estimated at about 0.121 .0 .51 for the urban area, 0.098 , and 0.036 for the countryside. This means that expenditure on poultry meat increases with an increase in the number of family members and monthly income, which indicates that poultry meat for the third category is a luxury commodity due to the decrease in the monthly income of the family with the increase in the number of individuals.

\section{References}

Central Agency for Public Mobilization and Statistics - Annual Statistical Book - Various Editions, 2019. A questionnaire for consumption of red, white and fish meat in Fayoum Governorate.

Econometric Study to Estimating the Demand of Meet in Egypt Using the Almost Ideal Demand System .

Hanan W. Gh. (Ph.D.) et.al, 2019. An Economic Study on the Possibility of Achieving Selfsufficiency of Animal Protein in Egypt - the Egyptian Journal of Agricultural Economics Volume Twenty-ninth $-1^{\text {st }}$ Edition - March.

Imam H.E. (Doctor) and E.A.A. Yassin (Ph.D.), 2018. An Economic Study of Fish Production and Marketing in Beni Suef Governorate - The Egyptian Journal of Agricultural Economics Twenty-eighth Volume $-4^{\text {th }}$ Edition - December.

Mashaal, A. A., 2018. J. Agric. Economy and Social Sci., Mansoura Univ., 9 (1): 71 - 76.

Nevin A. H. (Ph.D.) and S.M. Yemeni (Ph.D.), 2019. An Economic Study for the Production and Consumption of Broiler Chickens in Egypt - The Egyptian Journal of Agricultural Economics - Twenty-ninth Volume $-2^{\text {nd }}$ Edition - June (b) 